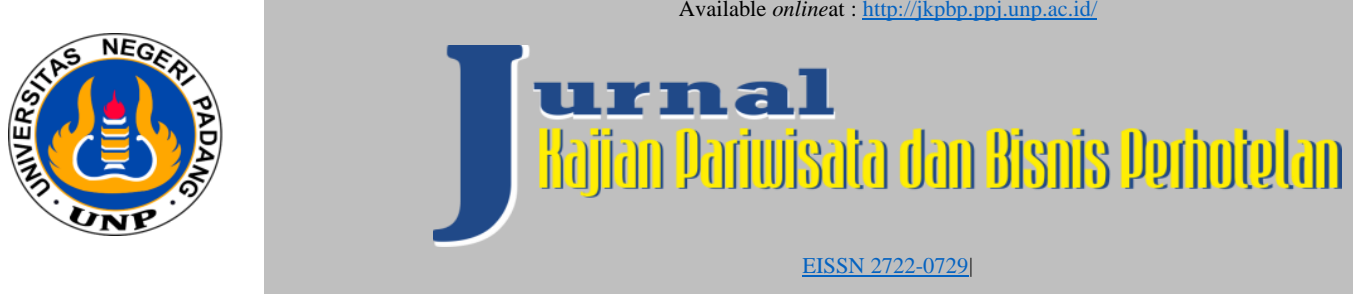

\title{
PERSEPSI PENGUNJUNG TENTANG SARANA DAN PRASARANA OBJEK WISATA RUMAH POHON TABEK PATAH
}

\author{
Vina Ananda ${ }^{1}$, Ira Meirina Chair ${ }^{2}$ \\ ${ }^{1}$ Universitas Negeri Padang \\ ${ }^{2}$ Universitas Negeri Padang
}

Email : vinaananda111@yahoo.co.id

\begin{abstract}
A B S T R A K
Latar belakang penelitian ini berawal dari adanya beberapa keluhan dari para pengunjung terkait sarana dan prasarana di objek wisata Rumah Pohon Tabek Patah. Penelitian ini tergolong pada penelitian deskiptif kuantitatif dengan metode survei. Populasinya dalam penelitian adalah para wisatawan yang berkunjung ke tujuan wisata Rumah Pohon Tabek Patah, teknik sampel dalam penelitian ini merupakan teknik non probability sampling yaitu purposive sampling, dengan jumlah sampel sebanyak 89 sampel. Pengumpulan data dilakukan dengan cara menyebarkan kuesioner menggunakan skala likert denagn lima pilihan jawaban. Jumlah pernyataan sebanyak 22 buah pernyataan yang telah diuji validitas dan reliabilitasnya dengan program SPSS 20.

Hasil penelitian terkait persepsi pengunjung terhadap sarana dan prasarana objek wisata Rumah Pohon Tabek Patah ini tergolong kategori baik (88,76\%). Apabila ditinjau dari indikator variabel adalah variabel sarana (1) Perusahaan transportasi tergolong kategori baik $(84,27 \%)$, (2) Hotel dan jenis akomodasi lainnya tergolong kategori baik $(93,26 \%)$, (3) Restoran serta rumah makan lainnya tergolong kategori baik $(84,27 \%)$, (4) Objek dan daya tarik wisata tergolong kategori baik $(74,16 \%)$, variabel prasarana adalah (1) Prasarana perhubungan tergolong kategori cukup (86,52\%), (2) Listrik/ penerangan tergolong kategori baik (93,26\%), (3) Air bersih tergolong kategori cukup (84,27\%), (4) Sistem telekomunikasi tergolong kategori cukup $(91,01 \%)$, (5) Kesehatan dan keamanan tergolong kategori baik $(83,15 \%)$.
\end{abstract}

Kata kunci : Persepsi, Pengunjung, Sarana dan Prasarana

\section{PENDAHULUAN}

Perkembangan industri pariwisata saat ini cukup signifikan. Pertumbuhan industri kepariwisataan tentunya telah memberikan dampak positif terhadap perekonomian masyarakat, sumber devisa dan memberikan kesempatan kerja untuk meningkatkan pendapatan masyarakat yang tinggal di sekitar industri pariwisata tersebut. Sektor kepariwisataan dimanfaatkan sebagai tempat pertamasyaan/ rekreasi, selain itu pawisata juga dimanfaatkan untuk pelestarian alam dan budaya setempat serta memenuhi kebutuhan masyarakat akan infrastruktur. Hal yang dapat menarik wisatawan untuk berkunjung yaitu keunikan dan kekhasan objek wisata tersebut yang tidak bisa kita temukan di tempat lain. Keunikan dan kekhasan suatu objek wisata merupakan potensi yang dapat dikembangkan dan dipromosikan untuk menarik minat wisatawan berkunjung ke objek wisata tersebut [1]. Pengembangan objek wisata tentunya membutuhkan peran serta dan dukungan dari para skakeholders pariwisata [2]. Salah satu unsur 
pendukung dalam mengembangkan sebuah objek wisata adalah prasarana dan sarana yang dimiliki oleh objek wisata tersebut, Kesan atau persepsi pengunjung tentang infratruktur dan fasilitas yang telah dimiliki suatu objek wisata dapat menjadi dasar untuk melakukan pengembangan [3].

Sarana Pariwisata adalah segala kelengkapan daerah tujuan wisata yang diperlukan untuk melayani kebutuhan wisatawan dalam menikmati perjalanan wisatanya yaitu terdiri dari perusahaan-perusahaan yang memberikan pelayanan kepada wisatawan, baik secara langsung maupun secara tidak langsung dan kehidupannya banyak bergantung pada kedatangan wisatawan [5]. Prasarana adalah semua fasilitas yang memungkinkan proses perekonomian berjalanan dengan lancar sehingga memudahkan para wisatawan untuk memenuhi kebutuhannya [6]. Indikator sarana yang digunakan dalam penelitian ini adalah perusahaan transportasi, hotel dan sarana akomodasi, restoran dan rumah makan serta objek dan daya Tarik wisata [7]. Sedangkan indicator prasarana yang digunakan dalam penelitian ini adalah prasaraha perhubungan, listrik atau penerangan, air bersih,system telekomunikasi, dan Kesehatan keamanan di objek wisata [8].

Rumah Pohon Tabek Patah merupakan salah satu tujuan wisata yang mampu menjadi perhatian wisatawan untuk berkunjung dengan keunikan yang dimilikinya. Objek wisata ini mulai beroperasi dari tahun 2015, memiliki luas \pm 4 hektare berlokasi di Puncak Bukit Keputusan Nagari Tabek Patah, Kecamatan Salimpaung. Wisatawan yang berkunjung ke objek wisata Rumah Pohon Tabek Patah ini mengalami peningkatan setiap tahunnya, hal ini bisa dijadikan suatu peluang dalam mengembangkan sebuah objek wisata. Sarana dan prasarana termasuk salah satu hal yang berpengaruh terhadap pengembangan objek wisata. Sarana dan prasarana yang tidak sesuai dengan harapan wisatawan dan tidak lengkap akan mempengaruhi kesan wisatawan pada saat berkunjung dan akan berdampak kepada penurunan jumlah kunjungan dan komplain dari wisatawan. Oleh karena itu penulis mengangkat penelitian tentang persepsi pengunjung terhadap sarana dan prasarana objek wisata Rumah Pohon Tabek Patah. Dari penjelasan diatas, maka peneliti tertatik untuk melakukan penelitian mengenai "Persepsi Pengunjung Terhadap Sarana dan Prasarana Objek Wisata Rumah Pohon Tabek Patah".

\section{METODOLOGI}

Penelitian yang dilakukan tergolong ke dalam penelitian deskriptif kuantitatif dengan metode survei [9]. Populasinya terdiri dari wisatawan yang pernah berkunjung ke objek wisata Rumah Pohon Tabek Patah dengan teknik pengambilan sampel yaitu non probability sampling dengan purposive sampling [10]. Jumlah sampel sebanyak 89 responden. Teknik pengambilan data yaitu dengan cara menyebarkan kuesioner menggunakan skala likert dengan empat pilihan jawaban. Jumlah pernyataan sebanyak 22 butir soal serta telah diuji validitas dan reliabilitasnya menggunakan program SPSS versi 18.00 .

\section{HASIL PENELITIAN DAN PEMBAHASAN}

\section{A. Hasil Penelitian}

\section{Deskripsi Data Variabel Sarana dan Prasarana}

Berdasarkan data yang terkumpul dari 89 orang responden yang terdiri dari 22 pernyataan pada variabel sarana $(\mathrm{X} 1)$ dan prasarana $(\mathrm{X} 2)$ sebagai berikut: 
Tabel 1. Klasifikasi skor variabel sarana dan prasarana

\begin{tabular}{|c|c|c|c|}
\hline Kategori & Rentang skor & Frekuensi & Persentase(\%) \\
\hline Sangat Baik & $3,26-4,00$ & 4 & $4,50 \%$ \\
\hline Baik & $\mathbf{2 , 5 1 - 3 , 2 5}$ & $\mathbf{7 9}$ & $\mathbf{8 8 , 7 6} \%$ \\
\hline Cukup & $1,76-2,50$ & 6 & $6,74 \%$ \\
\hline Kurang & $1,00-1,75$ & 0 & $0 \%$ \\
\hline \multicolumn{2}{|c|}{ Jumlah } & 89 & $100 \%$ \\
\hline
\end{tabular}

Sumber :Olah Data, 2020

Hasil olah data dari 89 responden untuk variabel sarana dan prasarana menunjukkan bahwa persepsi pengunjung terhadap sarana dan prasarana objek wisata Rumah Pohon Tabek Patah tergolong kategori baik $(88,76 \%)$.

Klasifikasi persepsi pengunjung dari masing-masing indikator variabel:

Variabel sarana

a. Perusahaan transportasi

Hasil penelitian ditinjau dari indikator perusahaan transportasi sebagai berikut:

Tabel 2. Klasifikasi skor indikator perusahaan transportasi

\begin{tabular}{|c|c|c|c|}
\hline Kategori & Rentang skor & Frekuensi & Persentase(\%) \\
\hline Sangat Baik & $3,26-4,00$ & 5 & $5,62 \%$ \\
\hline Baik & $\mathbf{2 , 5 1 - 3 , 2 5}$ & $\mathbf{7 5}$ & $\mathbf{8 4 , 2 7} \%$ \\
\hline Cukup & $1,76-2,50$ & 8 & $8,99 \%$ \\
\hline Kurang & $1,00-1,75$ & 1 & $1,12 \%$ \\
\hline \multicolumn{2}{|r|}{ Jumlah } & 89 & $100 \%$ \\
\hline
\end{tabular}

Sumber: Olah Data, 2020

Berdasarkan olah data dari 89 responden untuk indikator perusahaan transportasi menunjukkan hasil penelitian tergolong kategori baik $(84,27 \%)$.

b. Hotel dan jenis akomodasi lainnya

Hasil penelitian ditinjau dari indikator hotel dan jenis akomodasi lainnya sebagai berikut:

Tabel 3. Klasifikasi skor indikator hotel dan jenis akomodasi lainnya

\begin{tabular}{|c|c|c|c|}
\hline Kategori & Rentang skor & Frekuensi & Persentase(\%) \\
\hline Sangat Baik & $3,26-4,00$ & 4 & $4,49 \%$ \\
\hline Baik & $\mathbf{2 , 5 1 - 3 , 2 5}$ & $\mathbf{8 3}$ & $\mathbf{9 3 , 2 6 \%}$ \\
\hline Cukup & $1,76-2,50$ & 2 & $2,25 \%$ \\
\hline Kurang & $1,00-1,75$ & 0 & $0 \%$ \\
\hline \multicolumn{2}{|c|}{ Jumlah } & 89 & $100 \%$ \\
\hline
\end{tabular}

Sumber :Olah Data, 2020 
Hasil olah data dari 89 responden untuk indikator hotel dan jenis akomodasi lainnya menunjukkan hasil penelitian tergolong kategori baik $(93,26 \%)$.

c. Restoran serta rumah makan lainnya

Hasil penelitian ditinjau dari indikator restoran serta rumah makan lainnya sebagai berikut:

Tabel 4. Klasifikasi skor indikator restoran serta rumah makan lainnya

\begin{tabular}{|c|c|c|c|}
\hline Kategori & Rentang skor & Frekuensi & Persentase(\%) \\
\hline Sangat Baik & $3,26-4,00$ & 5 & $5,62 \%$ \\
\hline Baik & $\mathbf{2 , 5 1 - 3 , 2 5}$ & $\mathbf{7 5}$ & $\mathbf{8 4 , 2 7 \%}$ \\
\hline Cukup & $1,76-2,50$ & 8 & $8,99 \%$ \\
\hline Kurang & $1,00-1,75$ & 1 & $1,12 \%$ \\
\hline \multicolumn{2}{|c|}{ Jumlah } & 89 & $100 \%$ \\
\hline
\end{tabular}

Sumber: Olah Data, 2020

Berdasarkan olah data dari 89 responden untuk indikator restoran serta rumah makan lainnya menunjukkan hasil penelitian tergolong kategori baik $(84,27 \%)$.

d. Obyek daya tarik wisata

Hasil penelitian ditinjau dari indikator objek dan daya tarik wisata sebagai berikut:

Tabel 5. Klasifikasi skor indikator objek dan daya tarik wisata

\begin{tabular}{|c|c|c|c|}
\hline Kategori & Rentang skor & Frekuensi & Persentase (\%) \\
\hline Sangat Baik & $3,26-4,00$ & 16 & $17,98 \%$ \\
\hline Baik & $\mathbf{2 , 5 1 - 3 , 2 5}$ & $\mathbf{6 6}$ & $\mathbf{7 4 , 1 6 \%}$ \\
\hline Cukup & $1,76-2,50$ & 7 & $7,86 \%$ \\
\hline Kurang & $1,00-1,75$ & 0 & $0 \%$ \\
\hline \multicolumn{2}{|c|}{ Jumlah } & 89 & $100 \%$ \\
\hline
\end{tabular}

Sumber : Olah Data, 2020

Hasil olah data dari 89 responden untuk indikator objek dan daya tarik wisata menunjukkan hasil penelitian tergolong kategori baik $(74,16 \%)$.

Variabel prasarana

a. prasarana perhubungan

Hasil penelitian ditinjau dari indikator prasarana perhubungan sebagai berikut: 
Tabel 6. Klasifikasi skor indikator prasarana perhubungan

\begin{tabular}{|c|c|c|c|}
\hline Kategori & Rentang skor & Frekuensi & Persentase(\%) \\
\hline Sangat Baik & $3,26-4,00$ & 3 & $3,37 \%$ \\
\hline Baik & $2,51-3,25$ & 9 & $10,11 \%$ \\
\hline Cukup & $\mathbf{1 , 7 6 - 2 , 5 0}$ & $\mathbf{7 7}$ & $\mathbf{8 6 , 5 2 \%}$ \\
\hline Kurang & $1,00-1,75$ & 0 & $0 \%$ \\
\hline \multicolumn{2}{|c|}{ Jumlah } & 89 & $100 \%$ \\
\hline
\end{tabular}

Sumber :Olah Data, 2020

Hasil olahan data dari 89 responden untuk indikator prasarana perhubungan menunjukkan hasil penelitian tergolong kategori cukup $(86,52 \%)$.

b. Listrik/ penerangan

Hasil penelitian ditinjau dari indikator listrik/ penerangan sebagai berikut:

Tabel 7. Klasifikasi skor indikator listrik/ penerangan

\begin{tabular}{|c|c|c|c|}
\hline Kategori & Rentang skor & Frekuensi & Persentase(\%) \\
\hline Sangat Baik & $3,26-4,00$ & 3 & $3,37 \%$ \\
\hline Baik & $\mathbf{2 , 5 1 - 3 , 2 5}$ & $\mathbf{8 3}$ & $\mathbf{9 3 , 2 6 \%}$ \\
\hline Cukup & $1,76-2,50$ & 3 & $3,37 \%$ \\
\hline Kurang & $1,00-1,75$ & 0 & $0 \%$ \\
\hline \multicolumn{2}{|r|}{ Jumlah } & 89 & $100 \%$ \\
\hline
\end{tabular}

Sumber :Olah Data, 2020

Hasil olah data dari 89 responden untuk indikator listrik/ perhubungan menunjukkan hasil penelitian tergolong kategori baik $(93,26 \%)$.

c. Air bersih

Hasil penelitian ditinjau dari indikator air bersih sebagai berikut:

Tabel 8. Klasifikasi skor indikator air bersih

\begin{tabular}{|c|c|c|c|}
\hline Kategori & Rentang skor & Frekuensi & Persentase(\%) \\
\hline Sangat Baik & $3,26-4,00$ & 3 & $3,37 \%$ \\
\hline Baik & $2,51-3,25$ & 11 & $12,36 \%$ \\
\hline Cukup & $\mathbf{1 , 7 6 - 2 , 5 0}$ & $\mathbf{7 5}$ & $\mathbf{8 4 , 2 7 \%}$ \\
\hline Kurang & $1,00-1,75$ & 0 & $0 \%$ \\
\hline \multicolumn{2}{|r|}{ Jumlah } & 89 & $100 \%$ \\
\hline
\end{tabular}

Sumber :Olah Data, 2020

Hasil olah data dari 89 responden untuk indikator air bersih menunjukkan hasil penelitian tergolong kategori cukup $(84,27 \%)$. 


\section{d. Sistem telekomunikasi}

Hasil penelitian ditinjau dari indikator sistem telekomunikasi sebagai berikut:

Tabel 9. Klasifikasi skor indikator sistem telekomunikasi

\begin{tabular}{|c|c|c|c|}
\hline Kategori & Rentang Skor & Frekuensi & Persentase(\%) \\
\hline Sangat Baik & $3,26-4,00$ & 3 & $3,37 \%$ \\
\hline Baik & $2,51-3,25$ & 4 & $4,50 \%$ \\
\hline Cukup & $\mathbf{1 , 7 6 - 2 , 5 0}$ & $\mathbf{8 1}$ & $\mathbf{9 1 , 0 1 \%}$ \\
\hline Kurang & $1,00-1,75$ & 1 & $1,12 \%$ \\
\hline \multicolumn{2}{|c|}{ Jumlah } & 89 & 100 \\
\hline
\end{tabular}

Sumber: Olah Data, 2020

Berdasarkan olah data dari 89 responden untuk indikator sistem telekomunikasi menunjukkan hasil penelitian tergolong kategori cukup $(91,01 \%)$.

e. Kesehatan dan keamanan

Hasil penelitian ditinjau dari indikator kesehatan dan keamanan sebagai berikut:

Tabel 10. Klasifikasi skor indikator kesehatan dan keamanan

\begin{tabular}{|c|c|c|c|}
\hline Kategori & Rentang skor & Frekuensi & Persentase(\%) \\
\hline Sangat Baik & $3,26-4,00$ & 14 & $15,73 \%$ \\
\hline Baik & $\mathbf{2 , 5 1 - 3 , 2 5}$ & $\mathbf{7 4}$ & $\mathbf{8 3 , 1 5 \%}$ \\
\hline Cukup & $1,76-2,50$ & 1 & $1,12 \%$ \\
\hline Kurang & $1,00-1,75$ & 0 & $0 \%$ \\
\hline \multicolumn{2}{|r|}{ Jumlah } & 89 & $100 \%$ \\
\hline
\end{tabular}

Sumber :Olah Data, 2020

Hasil olah data dari 89 responden untuk indikator kesehatan dan keamanan menunjukkan hasil penelitian tergolong kategori baik $(83,15 \%)$.

\section{B. Pembahasan}

Setelah dilakukan penelitian bahwa persepsi pengunjung terhadap sarana dan prasarana objek wisata Rumah Pohon Tabek Patah yang didapat dari 89 responden tergolong kategori baik dengan persentase $88,76 \%$ yang berarti sarana dan prasarana objek wisata Rumah Pohon Tabek Patah sudah bagus dilihat dari sudut pandang pengunjung.

Persepsi pengunjung ditinjau dari masing-masing indikator:

1. Variabel sarana (X1)

a. Persepsi pengunjung ditinjau dari indikator perusahaan transportasi tergolong baik dengan persentase $84,27 \%$, artinya sarana perusahaan transportasi dilihat dari sudut pandang pengunjung sudah bagus.

b. Persepsi pengunjung ditinjau dari indikator hotel dan jenis akomodasi lainnya tergolong baik dengan persentase $93,26 \%$, artinya sarana hotel dan jenis akomodasi lainnya dilihat dari sudut pandang pengunjung sudah bagus.

c. Persepsi pengunjung ditinjau dari indikator restoran serta rumah makan lainnya tergolong baik dengan persentase $84,27 \%$, artinya sarana restoran serta rumah makan lainnya dilihat dari sudut pandang pengunjung sudah bagus. 
d. Persepsi pengunjung ditinjau dari indikator objek dan daya tarik wisata tergolong baik dengan persentase $74,16 \%$, artinya objek dan daya tarik wisata dilihat dari sudut pandang pengunjung sudah bagus.

2. Variabel prasarana (X2)

a. Persepsi pengunjung ditinjau dari indikator prasarana perhubungan tergolong cukup dengan persentase $86,52 \%$, artinya prasarana perhubungan dilihat dari sudut pandang pengunjung masih belum bagus.

b. Persepsi pengunjung ditinjau dari indikator listrik/ penerangan tergolong baik dengan persentase $93,26 \%$, artinya prasarana listrik/ penerangan dilihat dari sudut pandang pengunjung sudah bagus.

c. Persepsi pengunjung ditinjau dari air bersih tergolong cukup dengan persentase $84,27 \%$, artinya prasarana air bersih dilihat dari sudut pandang pengunjung masih belum bagus.

d. Persepsi pengunjung ditinjau dari indikator sistem telekomunikasi tergolong cukup dengan persentase $91,01 \%$, artinya prasarana sistem telekomunikasi dilihat dari sudut pandang pengunjung masih belum bagus.

e. Persepsi pengunjung ditinjau dari indikator kesehatan dan keamanan tergolong baik dengan persentase $83,15 \%$ artinya prasarana kesehatan dan keamanan dilihat dari sudut pandang pengunjung sudah bagus.

Berdasarkan hasil penelitian untuk variabel sarana semua indikator yang digunakan dalam penelitian berada dalam kategori baik, jadi kesan yang di dapat oleh mayoritas pengunjung tentang sarana di objek wisata Rumah Pohon Tabek Patah sudah sesuai harapan dari mayoritas pengunjung. Dengan adanya sarana pariwisata yang dikelola oleh masyarakat sekitar tentunya akan berdampak dalam peningkatan perekonomian masyarakat[4]. Masyarakat disekitar objek wisata akan mendapatkan income tambahan dari para pengunjung yang dating ke objek wisata tersebut.

Untuk variabel prasarana masih terdapat beberapa indikator pada kategori cukup, dimana indikator sarana perhubungan seperti akses menuju lokasi objek wisata, indikator air bersih dan indikator sistem telekomunikasi. Ketiga indikator prasarana yang belum memuaskan tersebut perlu menjadi perhatian untuk diperbaiki atau dikembangkan, guna mencapai harapan dari para pengunjung. Dalam pengembangan prasarana wisata memerlukan peran serta dari pemerintah. Dengan perbaikan dan pengembangan pada prasaranan wisata di Rumah Pohon Tabek Patah, tentunya diharapkan dapat meningkatkan kunjungan wisatawan ke objek wisata tersebut.

\section{KESIMPULAN}

Persepsi pengunjung terhadap sarana dan prasarana objek wisata Rumah Pohon Tabek Patah tergolong kategori baik $(88,76 \%)$. Apabila ditinjau dari indikator variabel sarana yaitu Perusahaan transportasi tergolong kategori baik $(84,27 \%)$, hotel dan jenis akomodasi lainnya tergolong kategori baik $(93,26 \%)$, restoran serta rumah makan lainnya tergolong kategori baik $(84,27 \%)$, objek dan daya tarik wisata tergolong kategori baik $(74,16 \%)$, variabel prasarana yaitu prasarna perhubungan tergolong kategori cukup $(86,52 \%)$, listrik/ penerangan tergolong kategori baik $(93,26 \%)$, air bersih tergolong kategori cukup $(84,27 \%)$, sistem telekomunikasi tergolong kategori cukup $(91,01 \%)$, kesehatan dan keamanan tergolong kategori baik $(83,15 \%)$.

\section{DAFTAR PUSTAKA}

[1] T. Putra, P. Pasaribu, and N. Wulansari, "Pemasaran Wisata Berbasis Website di Nagari Wisata Harau Kabupaten Lima Puluh Kota," J. Pengabdi. dan Pemberdaya. Masy., vol. 2, no. 1, pp. 1827, 2020, doi: https://doi.org/10.24036/abdi/vol1-iss2/8.

[2] T. Putra, "a Review on Penta Helix Actors in Village Tourism Development and Management," J. Bus. Hosp. Tour., vol. 5, no. 1, pp. 63-75, 2019, doi: 10.22334/jbhost.v5i1.150. 
[3] H. Azwar, P. Pasaribu, and H. Pramudia, "Ecotourism Development in Sungai Janiah, Agam: the Paradigms From the Local Community," J. Bus. Hosp. Tour., vol. 5, no. 2, pp. 238-248, 2019, doi: 10.22334/jbhost.v5i2.173.

[4] D. P. WULANDARI, “ANALISIS DAMPAK PERKEMBANGAN PARIWISATATERHADAP PERUBAHAN KONDISI SOSIAL EKONOMI MASYARAKAT DESA KERSIK TUO KECAMATAN KAYU ARO KABUPATEN KERINCI DWI," ensiklopedia J., vol. 2, no. 1, pp. 241-249, 2019, doi: https://doi.org/10.33559/eoj.v1i1.19.

[5] A, Yoeti, Oka. 2016. Pengantar Ilmu Pariwisata. Bandung: Angkasa

[6] Sinarta, Riko Mirad. 2009. Upaya Pengembangan Objek Wisata Di Kabupaten Simuelue Pasca Tsunami. Medan: Universitas Sumatera Utara.

[7] Permadi, Adi. 2018. Persepsi dan Preferensi Wisatawa Muslim Terhadap Sarana dan Prasarana Wisata Halal di Lombok (Studi Kasus Kawasan Ekonomi Khusus Mandalika). Jurnal Sosial Ekonomi dan Humaniora (JSEH):

[8] Keliwar, Said. 2015. Motivasi dan Persepsi Pengunjung Terhadap Obyek Wisata Desa Budaya Pampang di Samarinda. Jurnal Manajemen Resort dan Leisure: Samarinda.

https://ejournal.upi.edu/index.php/jurel/article/viewFile/1462/1009

[9] Sugiyono. 2015. Metode Penelitian Kuantitatif, Kualitatif dan R\&D. Bandung: Alfabeta.

[10] Arikunto, Suharsimi. 2010. Prosedur Penelitian Suatu Pendekatan Praktik. Jakarta: Rineka Cipta.

[11] Morito, Dede. 2017. Persepsi Wisatawan Mancanegara Tentang Kualitas Pelayanan Front Desk Agent Hotel Berbintang Empat di Kota Padang. Padang. Universitas Negeri Padang. (Skripsi yang tidak dipublikasikan).

[12] Pengelola Objek Wisata Rumah Pohon Tabek Patah. 2020. Jumlah Kunjungan Wisatawan Rumah Pohon Tabek Patah Lima Tahun Terakhir. Tabek Patah. 